\title{
Barns tekstproduksjon på Snapchat: Multimodale svar på kommunikative forventninger og fiksjonalisering av det hverdagslige
}

\author{
Maja Michelsen \\ Høgskolen $i$ Østfold
}

\begin{abstract}
Sammendrag
Artikkelen tar for seg barns tekstproduksjon på Snapchat. Tekstmaterialet som ligger til grunn, er sekstisju snapper produsert av barn i alderen 9-15 år. Formålet er å undersøke hva som gjør at barna finner det meningsfullt å skape tekster i Snapchat-mediet. Et sentralt funn er at barna finner det å sette sammen ulike semiotiske ressurser meningsfullt i seg selv. Dette er likevel ikke motivasjonsfaktor alene. Motivasjonsfaktoren i verktøyet må ses i sammenheng med hva barna bruker verktøyet til. For det første er verktøyet egnet til å skape tekster som kan realisere mange ulike typer kommunikative formål, slik som å dokumentere hverdagshendelser, å gjøre avtaler, å sende hilsener, å fortelle fortellinger, å leke og å selvkommunisere. For det andre gir verktøyet barna mulighet til å fiksjonalisere de hverdagslige situasjonene de deltar i.
\end{abstract}

Nøkkelord: Snapchat; barn; tekstkompetanse; multimodalitet; fiksjonalisering

\begin{abstract}
Children's text production on Snapchat. Multimodal responses to communicative expectations and fictionalization of everyday events

The article deals with children's text production on Snapchat. The purpose is to investigate why children find it meaningful to create texts in this medium. The text material consists of Snapchat texts produced by children aged 9-15. A key finding is that the children find putting together various semiotic resources a main motivation in itself. However, this is not a motivating factor alone. The motivation factor of the tool must be seen in the context of what the children use the tool for. First, the tool is suitable for creating texts that can realize many different types of communicative purposes, such as documenting everyday events, making appointments, sending greetings, telling stories, playing and self-communicating. Second, the tool allows the children to fictionalize the everyday situations in which they participate.
\end{abstract}

Keywords: Snapchat; children; literacy; multimodality; fictionalization

Guest editor: Gudrun Kløve Juuhl

Received: December, 2019: Accepted: October, 2020; Published: December, 2020

^Korrespondanse: Maja Michelsen, e-post: maja.michelsen@hiof.no

(C) 2020 Maja Michelsen. This is an Open Access article distributed under the terms of the Creative Commons Attribution 4.0 International License (https://creativecommons.org/licenses/by-nc/4.0/), allowing third parties to copy and redistribute the material in any medium or format and to remix, transform, and build upon the material for any purpose, even commercially, provided the original work is properly cited and states its license.

Citation: M. Michelsen. "Barns tekstproduksjon på Snapchat: Multimodale svar på kommunikative forventninger og fiksjonalisering av det hverdagslige" Nordic fournal of Literacy Research, Special issue: Barn og unges tekstpraksiser i fritiden, 6(3), 2020,115-135. http://dx.doi.org/10.23865/njlr.v6.2059 115 


\section{Michelsen}

\section{Innledning}

Medietilsynets rapporter Barn og medier fra 2016 og 2018 viser at Snapchat er det mest foretrukne sosiale mediet blant barn i alderen 9 til 18 år de siste årene. Såkalt snapping er altså en svært vanlig tekstaktivitet blant norske barn, og i denne artikkelen ønsker jeg å finne svar på hva som gjør at så mange barn og unge finner denne aktiviteten meningsfull. I Norge er anbefalt aldersgrense på sosiale medier 13 år, ${ }^{1}$ men Medietilsynets rapporter viser at også yngre barn enn dette bruker sosiale medier. Deltakerne i dette forskningsprosjektet er åtte barn i alderen 9-15 år som har ulike erfaringer med Snapchat. Tekstmaterialet består av sekstisju snapper ${ }^{2}$ som er produserte av disse barna. Materialet består også av svar på fire spørsmål om bruk av mediet som barna har besvart skriftlig.

Å undersøke barns tekstengasjement på Snapchat vil gi innsikt i barns tekstlige hverdagsliv generelt, slik det utfolder seg på fritiden. Samtidig vil det kunne bidra til noen didaktiske innsikter som angår barns multimodale tekstkompetanse. På sosiale medier har barn og unge behov for å kunne være kritiske til ytringer de skaper og mottar. Kritisk tilncerming til tekst er ett av seks kjerneelementer i norskfaget i den reviderte versjonen av læreplanverket for Kunnskapsløftet (LK20), og kritisk tenkning er også en verdi som gjennomsyrer hele læreplanverket. Både tematisering av teksters forhold til virkeligheten og selvframstilling er dermed relevant i norskdidaktisk sammenheng.

Når barn snapper, produserer de statiske bilder, men også videosnutter eller såkalte kineikoniske tekster (Burn \& Parker, 2003). Et viktig redskap i tekstproduksjonen er Snapchat-kameraet (se figur 1) som gir muligheter for å kle seg ut, eksempelvis gjennom å få dyreører og snute, eller å forvrenge ansikt og stemme. Tekstene kan også settes sammen ved hjelp av skrift, emojis og såkalte «stickers» som kan betraktes som digitale klistremerker. Verktøyet innbyr dermed til å skape tekster der multimodalitet kan utnyttes i høy grad. Et annet trekk ved verktøyet er at det reagerer på barnets kroppslige bevegelse. Barnet produserer ikke bare tekst ved å trykke på skjermen, men også gjennom å bevege seg foran kameraet. Denne type kroppslige dimensjon ved tekstskaping blir hos Mills (2016) kalt for sensorisk literacy.

I artikkelen undersøker jeg tekstskaping på Snapchat ved å se på hvordan snappene er koplet opp mot de situasjonene som barna deltar i når de snapper. Problemstillingen Hva gjør at barn og unge finner det meningsfullt å skape tekster på Snapchat? er operasjonalisert i to forskningsspørsmål det er mulig å besvare gjennom å analysere tekstene og det barna sier om dem: 1. Hvordan ser de kommunikative situasjonene der barna produserer snapchattekster ut? 2. Hva slags innhold formidles til mottakeren, og hvordan gjøres det?

\footnotetext{
${ }^{1}$ Denne anbefalingen er tydelig hos Redd Barna, Medietilsynet og Barneombudet.

${ }^{2}$ Ordene snap og tekst er brukt som synonymer i artikkelen.
} 
Til grunn for det første forskningsspørsmålet ligger det en forståelse av at tekster er del av sosiale praksiser (Barton \& Hamilton, 2003). Barton \& Hamilton (2003) bruker begrepet tekstpraksis (literacy practice) om de etablerte måtene å forholde seg til tekster på. Tekstpraksiser formes av at mennesker deltar i repeterte tekstlige aktiviteter som likner hverandre over tid. Tekstpraksisen er ikke synlig, men normer, verdier og holdninger som preger praksisen kan likevel komme til syne i tekstene. Et nærliggende perspektiv finner vi hos Halliday (1998), som har vist hvordan tekster står i et dynamisk forhold til konteksten. Det at sosiale aktiviteter repeteres og bidrar til forutsigbare måter å kommunisere på, er også sentralt innenfor nyretorisk sjangerforståelse (Miller, 2001). En slik retorisk forståelse av kommunikasjon innebærer at tekster er svar på konvensjonelle forventninger ved at de løser et retorisk problem eller en mangel, og at disse er gjentakende i kulturen. Denne type forutsigbarhet må likevel ikke forveksles med en oppfatning av sjangre som statiske størrelser (Miller, 2001). Når jeg undersøker snappene som del av sosiale praksiser, er jeg opptatt av å finne ut hva kommunikasjonen brukes til å oppnå. Eksempelvis vil en situasjon der barnet trenger å gjøre en avtale med en venn kunne løses tekstlig gjennom å snappe. En slik forståelse er også i tråd med nyere sosialsemiotiske tilnærminger, slik som eksempelvis Ledin \& Machin (2018).

Til grunn for det andre forskningsspørsmålet ligger det en forståelse av at hver enkelt snapp er et såkalt integrert design (Ledin \& Machin, 2018). Det vil si at det gjerne er fravær av løpende tekst, og at de ulike modalitetene fungerer sammen som én helhetlig størrelse (Ledin \& Machin, s. 29). For å få innsikt i hva som motiverer barn til tekstskaping, må snappene studeres som slike meningsfulle helheter som formidler noe til noen i en sosial og kulturell kontekst. Forskning på barns tekstproduksjon $\mathrm{i}$ andre sammenhenger har vist at barn har mottakerbevissthet, og at det å ytre seg til noen er en sentral motivasjonsfaktor i barns tekstskaping, også hos de tidligste skriverne (se f.eks. Lorentzen, 2009).

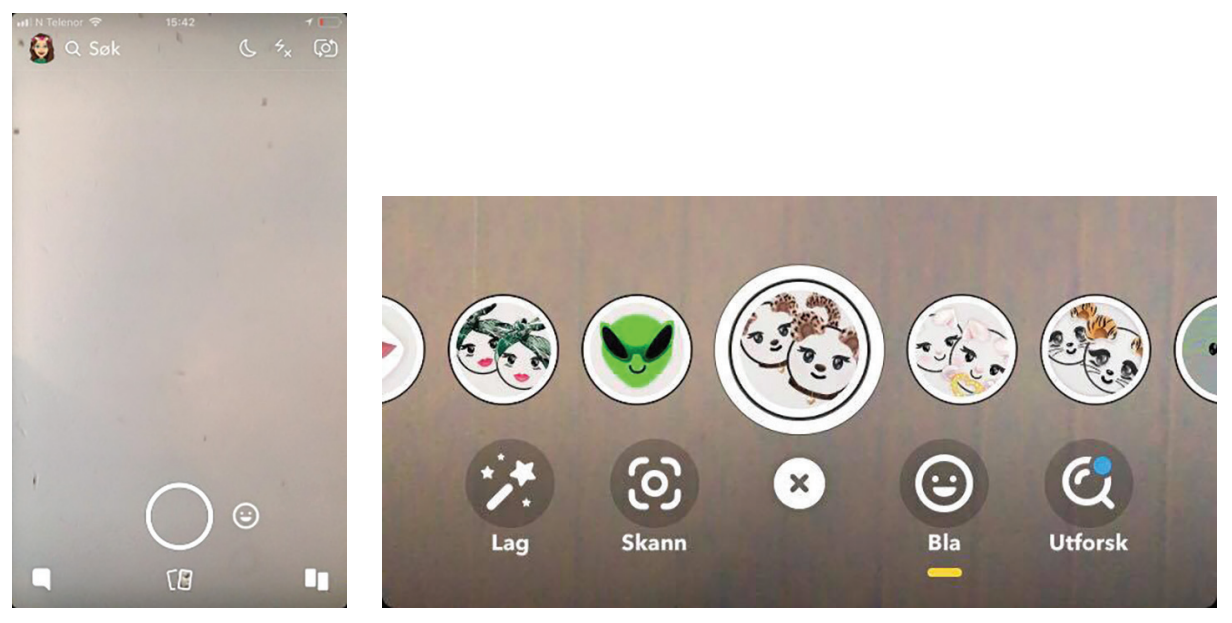

Figur 1. Snapchat-kameraet (t.v.) og filterfunksjoner (t.h.) 


\section{Snapchat som tekstpraksis}

I forskningen på multimodalitet er det tradisjon for å studere hvordan barn uttrykker seg visuelt, særlig gjennom tegning (se f.eks. Hopperstad, 2005; Kress \& van Leeuwen, 2006; Lindstrand, 2011; Semundseth \& Hopperstad red., 2013). Barns tekstuttrykk i digitale medier på fritiden er også viet oppmerksomhet, og tekster som har vært gjenstand for undersøkelse i norsk kontekst er f.eks. tekstmeldinger (Ringdal, 2002), blogg (Juuhl, 2014; Veum, 2013) og musikkvideo i Musikally ${ }^{3}$ (Rettberg, 2017). Snapping er i mindre grad utforsket fra et tekstperspektiv. En gjennomgang av nordisk forsking på feltet fritidstekster (Juuhl \& Michelsen 2020), viser at empiri som angår unges bruk av Snapchat og andre sosiale medier, primært er samlet inn ved å bruke intervju og spørreundersøkelser (se f.eks. Hilmarsen \& Arnseth, 2017; Wernholm, 2018). Det fins imidlertid unntak, og Undrum og Veum (2018) har samlet inn slike tekster fra elever på videregående.

Tekstproduksjon på Snapchat vil preges av selfien, og også dette fenomenet er studert avVeum og Undrum i en annen artikkel fra 2018. Ifølge disse forskerne er selfien en uttrykksmåte som har likhetstrekk med reklame, og som er felles i den globale kulturen. Også forskere fra fagfelt som psykologi, medievitenskap og kulturstudier har vært opptatt av selfien. Flere peker på hvordan selfien kan forstås som kulturelt og psykologisk fenomen som har sitt opphav i selvportrettet (se f.eks. Rettberg, 2014; Skårderud, 2013). I et selvportrett kan det være flytende overganger mellom det å være seg selv, å se seg selv utenifra og å iscenesette seg selv (Skårderud, 2013).

Internasjonalt fins det forskning som kan bidra til innsikt i hva som kjennetegner tekstpraksisen. I en survey-undersøkelse finner Piwek \& Joinson (2016) at Snapchat primært brukes som kommunikasjonsform mellom personer som står hverandre nær. Det samme finner Vaterlaus et al. (2016), som hevder at Snapchat brukes til å styrke allerede eksisterende sosiale bånd. Piwek \& Joinson (2016) bruker begrepene bonding og bridging for å beskrive den kontakten som skapes gjennom sosiale medier. Bonding, som er kjennetegnende for Snapchat, vil si at bruken av mediet styrker sosial kontakt med familie og venner. Denne måten å opprettholde kontakt på står i kontrast til f.eks. Facebook, som primært brukes til såkalt bridging, altså å ha mere overflatisk kontakt med et større og mere upersonlig nettverk. Wernholm (2018), som har intervjuet 8-12-åringer om deres bruk av sosiale medier, rapporterer at bruken er viktig for denne gruppa for å kunne sosialisere med venner, men også for å kunne følge med på ulike trender som angår populære spill eller populære filmklipp på YouTube.

Et tekstlig aspekt som ofte diskuteres når Snapchat problematiseres, er tekstenes flyktighet (se f.eks. Piwek \& Joinson, 2016; Vaterlaus et al., 2016). Det at snappene blir borte, gjør det eksempelvis vanskelig å etterspore krenkelser. Jeg betrakter flyktighet som ett av flere sentralt trekk ved tekstene. Filtrering kan også sies å være et sentralt tekstaspekt, noe Rettberg (2014) påpeker. Filtrering kan forstås på flere måter,

\footnotetext{
${ }^{3}$ I 2018 byttet Musikal.ly navn til Tik Tok.
} 
ifølge henne, både som konkrete filtre som nedtoner eller fremhever bestemte tekstdeler, men også som kulturelle filtre som gjør at vi tolker ting på bestemte måter i lys av ritualer, vaner eller fordommer (Rettberg, 2014, s. 32). Jovanovic og van Leeuwen (2018) er inne på noe av det samme når de skriver om hvordan filtrene kan forstås som stereotypiske maler. Disse er forutsigbare og klisjeaktige figurer som er gjengangere i kulturen og litteraturen. Det fins også likheter mellom Snapchat og muntlige sjangre. Jovanovic \& van Leeuwen (2018) trekker fram hverdagssamtalen som en sjangermessig forløper til kommunikasjon i sosiale medier.

\section{Forskningsdesign}

I prosjektet har jeg samlet inn snapper fra åtte barn i alderen 9-15 år. Barna ble rekruttert gjennom den såkalte snøballmetoden (Bryman 2016, s. 696). Det vil si at jeg tok kontakt med foreldre som hadde barn som kunne være aktuelle. Disse barna rekrutterte deretter søsken eller venner. Fire av barna kjente jeg fra før. De andre kjente jeg ikke. Det at barna rekrutterte hverandre, bidro til et forholdvis stort aldersspenn. På grunn av ulik alder hadde også barna ulike erfaringer med Snapchat. De tre eldste barna hadde egen brukerkonto, mens de fem yngste ikke hadde konto, men fikk lov til å utforske verktøyet på foreldrenes mobil. Tre av disse fikk også lov å sende snap til familiemedlemmer, og de hadde dermed erfaring med deling, i likhet med de eldste barna. To av barna som ikke delte snapper, hadde likevel erfaring med deling av tekster $\mathrm{i}$ andre sosiale medier, og da i form av bruk av tjenesten Tik Tok. Aldersspennet gjør at datamaterialet ikke sier noe om tekstproduksjonen til én bestemt aldersgruppe, men det kan gi innsikt i praksisen generelt, uavhengig av alder.

Jeg tok kontakt med de første barna og deres foreldre høsten 2018. Videre rekruttering og innsamling foregikk våren 2019. Barna sendte enten snappene selv, eller fikk hjelp av foreldrene. De fleste valgte å sende mange snapper om gangen over noen få dager. De fleste tekstene mottok jeg i perioden februar til mai 2019. De aller siste snappene fra to av deltakerne mottok jeg sommeren 2019. Samtlige barn ble invitert til å svare på følgende spørsmål: 1) Hva synes du er morsomt med Snapchat? 2) Er det noe du synes er dumt med Snapchat? 3) Hva handler de snappene du har sendt til meg om? 4) Hvem sender du oftest snap til? Dersom du ikke fär lov à sende snappene, hvem ville du delt snappene med hvis du fikk lov å sende dem? Svarene på spørsmålene kom også inn på ulike tidspunkter våren 2019. Barnas uttalelser om egen praksis så jeg på som hensiktsmessig for å supplere mine tekstanalyser og løfte fram barnas stemmer. ${ }^{4} \mathrm{De}$ ga meg dessuten informasjon om situasjonene som snappene hørte hjemme i.

Prosjektet er forhåndsgodkjent av NSD. Foreldrene mottok et informasjonsbrev og skrev under på samtykkeerklæring. Barna fikk et tilpasset informasjonsbrev og ble informert om at de ikke skulle dele hemmeligheter eller sende informasjon som berørte tredjepart. Barna har fått velge hvor mange og hvilke snapper de vil dele (se

\footnotetext{
${ }^{4}$ Barnas sitater er beholdt i original, og skrivefeil kan derfor forekomme.
} 
oversikt i figur 2). ${ }^{5}$ Siden barna har fătt hjelp av foreldrene, har de trolig hatt samtaler med foreldrene sine om dette. Det er sannsynlig at det at barna selv har valgt tekster, har påvirket datamaterialet i noen grad. Barna kan ha valgt vekk snapper de ikke liker, eller de kan ha laget snapper med informasjon som de tenker at jeg kan være interessert i. Materialet bærer likevel preg av at tekstene $i k k e$ er tiltenkt meg. Isteden er tekstene dokumentasjon på praksisen slik den ser ut utenfor forskningskonteksten. Seks av barna var venner eller søsken med av ett av de andre barna, og materialet inneholder flere snapper som er sendt disse barna imellom, eller til barnas foreldre. Et par av snappene er også delt i Snapchat Story. Noen av snappene er laget ved juletider, altså var de produsert før innsamlingen startet, og de var allerede lagret på en telefon.

\begin{tabular}{lccccccccc}
\hline Barn (alder) & $\begin{array}{c}\text { Oliver } \\
12 \text { år }\end{array}$ & $\begin{array}{c}\text { Anna } \\
9 \text { år }\end{array}$ & $\begin{array}{c}\text { Tilje } \\
9 \text { år }\end{array}$ & $\begin{array}{c}\text { Ida } \\
11 \text { år }\end{array}$ & $\begin{array}{c}\text { Sofie } \\
9 \text { år }\end{array}$ & $\begin{array}{c}\text { Malin } \\
13 \text { år }\end{array}$ & $\begin{array}{c}\text { Kristine } \\
15 \text { år }\end{array}$ & $\begin{array}{c}\text { Emil } \\
9 \text { år }\end{array}$ \\
\hline Antall snapper & 15 & 9 & 7 & 8 & 8 & 5 & 3 & 14 \\
\hline
\end{tabular}

Figur 2. Oversikt over barn, alder og antall snapper

Det å samle inn et større tekstmateriale fra Snapchat byr på en opplagt metodisk utfordring som angår flyktigheten ved tekstene. Fordi snappene forsvinner idet man mottar dem, var det nødvendig at barna tok skjermdumper av tekstene de ville dele. Jeg søkte om særlig dispensasjon for å kunne motta og mellomlagre tekstene på min egen mobil. Snappene ble deretter lagret på et sikkert sted og slettet fra mobilen.

Da snappene inneholder informasjon av privat karakter, har det vært svært viktig å ikke utøve press på barna om å dele. Jeg har også informert om barnas rett til å trekke seg fra prosjektet, og at det ikke skal utøves press om å delta. Videre har jeg informert om at barna vil bli anonymisert. Flere av barna har da faktisk uttrykt at det er dumt at de ikke kommer på trykk i denne artikkelen med sitt egentlige navn. Dette forteller meg at barna har syntes det har vært gøy å vise fram tekstene, og at de også er vant til å stå fram med ansikt i den sosiale delingskulturen.

Det begrensede antallet deltakere og snapper gjør at funnene ikke kan generaliseres til å gjelde alle barn i Norge. Det kan være andre måter å snappe på enn det som kommer fram i undersøkelsen. Materialet kan likevel si noe om vanlige måter å bruke verktøyet på blant de åtte barna. Gitt at tekstlige aktiviteter er gjentakende fenomener i kulturen, noe som er drøftet tidligere, mener jeg det er sannsynlig at andre barn vil kunne ha liknende teksterfaringer.

\section{Analysemodell og tekstutvalg}

En utfordring ved å analysere snapper er at de samlet sett framstår som lite homogene. I datamaterialet fins det snapper som er rene fotografier, mens andre er filmsnutter

\footnotetext{
${ }_{5}^{5}$ Malin og Kristine har sendt to snapper i fellesskap. Det sammenlagt tallet i denne tabellen er derfor 69, ikke 67 snapper.
} 
eller bilder kombinert med skrift. En måte å utføre analyse på som er vanlig innenfor den sosialsemiotiske tradisjonen, er å samle et stort nok materiale til at man kan forstå hva slags mønstre som er gjeldene, for så å gjøre detaljert analyse av typiske eksempler (Ledin \& Machin, 2018). For å nærme meg en fruktbar måte å undersøke datamaterialet på, er tekstene analysert i flere omganger. Femten snapper vises fram som typiske eksempler i analysen. Kriteriene for de tekstene som er tatt med, var at samtlige barn skulle være representerte i analysen. Tekstutvalget skulle også speile typiske tekster og situasjoner, men samtidig synliggjøre variasjonen i materialet. Trass i at barna bruker filtre i mange av snappene, har dette alene ikke vært tilstrekkelig for å anonymisere barna. Øyesladding av ansiktsbilder er derfor brukt i tillegg. En konsekvens av dette blir at en del av meningspotensialet i tekstene ikke blir tilgjengeliggjort for leseren. Isteden vil leseren måtte forholde seg til mine analyser av originalbildene der blikk som semiotisk ressurs er tatt med som en del av tekstanalysen.

For å kunne svare på de to forskningsspørsmålene er analysen gjennomført på to nivåer (se figur 3), der den første delen av analysen samsvarer med forskningsspørmål 1, og den andre delen samsvarer med forskningsspørsmål 2. I analysen undersøker jeg seks ulike sosiale situasjoner. Deretter nærleser jeg snappene og undersøker dem som semiotiske helheter. Til slutt i analysedelen ser jeg de analyserte situasjonene og tekstene opp mot det øvrige materialet. Det er viktig å påpeke at kameraet i seg selv innbyr til en bestemt sosial kontakt. Dersom man tar bilde med filterfunksjonen, vil blikket som oftest være vendt mot seeren, og bildet inviterer dermed til sosial involvering. Ofte vil også filtrene innby til et bildeutsnitt som er halvnært eller nært. Det ligger altså innbakt en forventning om sosial nærkontakt mellom avsender og mottakeren i verktøyet.

Når det gjelder å undersøke snappene som integrerte semiotiske helheter, er snappene analysert ved hjelp av utvalgte verktøy og begreper fra sosialsemiotikken, slik

\begin{tabular}{|c|c|c|c|c|}
\hline Situasjon & \multicolumn{3}{|c|}{ Deltakere og kommunikativt formål } & Hvem deltar og hva er formålet? \\
\hline \multirow[t]{6}{*}{ Snap } & \multicolumn{3}{|c|}{ Semiotiske ressurser } & Hvilke ressurser brukes til å formidle hva? \\
\hline & \multirow[t]{4}{*}{ Objekt } & Personer & $\begin{array}{l}\text { Stemmer } \\
\text { (rolleytringerl } \\
\text { personlige ytringer) }\end{array}$ & \multirow[t]{2}{*}{ Hvem avbildes? Hva sier og gjør de? } \\
\hline & & & Handlinger & \\
\hline & & \multicolumn{2}{|l|}{ Ting } & Hvilke ting vises fram? \\
\hline & & \multicolumn{2}{|c|}{ Sted (bakgrunn) } & $\begin{array}{l}\text { Hvor foregår det? Er bakgrunnen } \\
\text { kontekstualisert eller dekontektstualisert? }\end{array}$ \\
\hline & \multicolumn{3}{|c|}{ Koding, perspektiv og avstand } & $\begin{array}{l}\text { Hvordan kodes innholdet? Hva slags } \\
\text { avstand er det til innholdet? }\end{array}$ \\
\hline
\end{tabular}

Figur 3. Analysemodell 
disse blant annet framstilles hos Ledin og Machin (2018) i tradisjonen etter Kress og van Leeuwen (2006). Jeg har undersøkt hvilke semiotiske ressurser som tas i bruk, og hva de brukes til å formidle. Videre har jeg undersøkt det snappene helt konkret viser fram på det denotative nivået (Machin \& Ledin, 2018, s. 47). Det innebærer å se på hva som er objekt i snappene (personer og ting), og hvor det foregår (sted). Til personene som avbildes i tekstene vil det kunne være knyttet bestemte handlinger eller stemmer. Personenes stemmer kan realiseres både gjennom lyd eller gjennom skrift. Noen ytringer må forstås som rolleytringer, slik vi kjenner disse ytringene fra barnespråk i lek (se Høigård, 2013). Andre ytringer kan i større grad kobles til barnets ikke-fiktive jeg, fordi de ikke er koblet til lek på samme måte som rolleytringene. Disse kaller jeg personlige ytringer. Når det gjelder bakgrunnen i snappen, så kan også denne tilby informasjon om situasjonen og hvordan situasjonen skal forstås. Objekter kan enten være kontekstualiserte, altså at omgivelsene og bakgrunnen er detaljerte, eller dekontekstualiserte, der detaljer i bakgrunnen er fraværende (Kress \& van Leeuwen, 2006, s. 161).

Fordi filterfunksjonen brukes hyppig, har det vært relevant å undersøke bruk av denne. Farger, detaljer og lys i bilder kan brukes til å kode virkeligheten på ulike måter (Kress \& van Leeuwen, 2006, s. 163) eller å uttrykke følelser (Ledin \& Machin, 2018 , s. 81). Kodingen viser "what count as real», for å bruke en uttrykksmåte fra Kress og van Leeuwen (2006, s. 163). Visuell koding kan eksempelvis være høy og lav grad av naturalistisk koding, sensorisk koding og teknisk koding (Kress \& Van Leeuwen, 2006, s. 166). Dersom kameraet er vendt vekk fra personen som tar bilde, fungerer kameraet som et vanlig kamera, det vil si at det er mulig å ta bilder med naturalistisk koding, altså bilder der virkeligheten framstår «slik den er». Sammen med avstand og perspektiv kan koding si noe om hvordan innholdet skal forstås.

\section{Analyse av situasjoner og snapper}

Situasjon 1: Ida (11) leker seg med utkledningsfiltrene

Ida har sendt meg åtte snapper, hvor alle er selfier med utkledningsfilter. I seks av snappene dominerer bildemodaliteten alene, mens to av dem også inneholder skrift. I figur 4 vises tre av disse snappene.
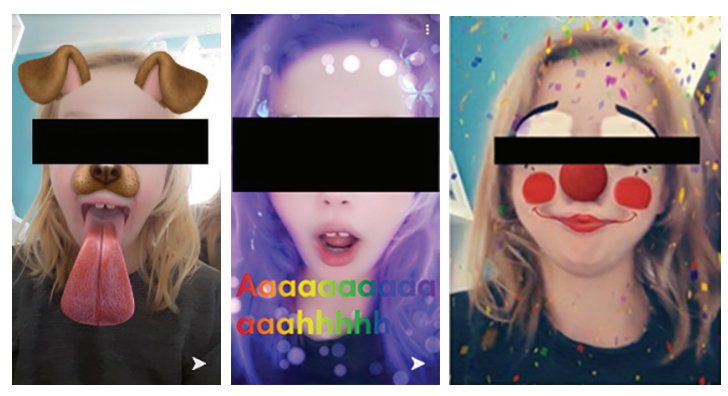

Figur 4. Idas snapper 
Ida har ikke egen Snapchat-konto, men får lov å bruke verktøyet på morens mobil. Det at Ida har sendt meg selfier med utkledningsfilter, og at hun ikke sender dem videre til noen, vitner om at hennes tekstproduksjon handler om uttesting av verktøyet. Formålet er å finne ut av hvordan hun blir seende ut med de ulike filtrene. Idas bilder kan forstås som en kjede av en slik uttesting, altså at hun har prøvd ut mange ulike filtre innenfor samme tidsrom. Det at snappene ble sendt meg samtidig, understøtter også at tekstene er uttrykk for én kommunikativ situasjon. At denne situasjonen har vært lekpreget og morsom, kommer fram i det Ida skriver om hva snappene handler om: «Det handler om å ha det gøy, og om glede». Den digitale utkledningen har en klar parallell til en kjent lekpreget situasjon fra barns hverdagsliv; nemlig det å stå foran et speil og prøve ut kostymer.

I de tre snappene som er vist over dominerer bildemodaliteten, og i alle bildene er Idas blikk rettet rett fram. I snappene til venstre og høyre er det Idas ansikt og øverste del av overkroppen som er synlig. I den midterste snappen er bildet tatt enda nærere. Både det direkte blikket og bildeinnrammingen bidrar til å skape en tett forbindelse mellom Ida bak kameraet og utkledningssitasjonen slik den foregår på skjermen. I den midterste snappen har Ida skrevet «aaaaaaah». Gjentakelsen av a-en kan symbolisere lydlig varighet. Det at skriften også er plassert ved den åpne munnen, gjør at skriften som helhet kan tolkes som et symbol på sang.

I samtlige snapper er det blandet koding. Ida, slik hun er synlig på bildene, er naturalistisk kodet. I to av snappene kan vi skimte noen naturtro elementer, slik som Idas hår i den første snappen, og Idas munn og nese i den andre. Kostymene har lav grad av naturalistisk koding. Kostymene er mere fargesterke enn Idas hår og ansikt, og disse framstår dermed som de mest fremskutte. Ida er dekontekstualisert i samtlige snapper. Selv om vi kan skimte noe som likner en turkis bakvegg i to av tekstene, er det ingen detaljer i bakgrunnen som forteller noe om hvor snappingen foregår. Settingen for utkledningssituasjonen framstår dermed som mindre viktig.

Snappingen til Ida resulterer i selvportretter med humoristisk vri. Kameraet fungerer som et karnevalspeil der Ida, i nær kontakt med sitt eget ansikt, kan observere seg selv i ulike roller. Selv om Ida bestemmer hvilke filtre hun vil teste, er hun ikke alene om å bestemme hva som skal være morsomt i bildene. Det digitale kostymene «tvinger» henne inn i bestemte karikaturer. Hun spiller også delvis ut disse rollene ved å gjøre eller si noe i rollen. I den første hunde-snappen strekker hun ut tunga, og i den andre snappen synger hun. I så måte er tekstene svar på forventninger som er innbakt i selve Snapchat-teknologien, og i denne situasjonen er det utkledningsfiltrene som spiller den viktigste rollen.

\section{Situasjon 2 og 3: Malin (13) og Kristine (15) dokumenterer hverdagshendelser}

Venninnene Malin og Kristine har til sammen sendt meg åtte snapper, og disse er sendt meg på ulike tidspunkter. Det vitner om at snappene representerer ulike situasjoner. To av snappene er sendt meg i fellesskap. Disse to snappene vises i figur 5, og de har til felles at de dokumenterer hverdagshendelser som venninnene deltar i. 


\section{Michelsen}

Den første viser fram at jentene lager kokosboller. Den andre viser fram at de spiser is på vei hjem fra skolen.

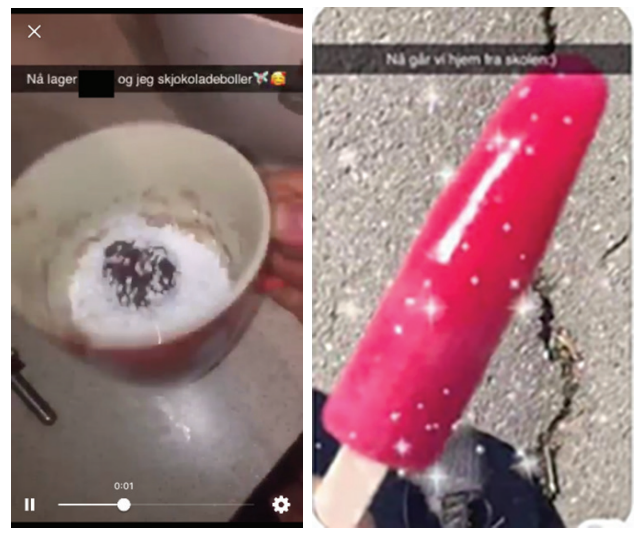

Figur 5. Malin og Kristines snapper

Begge snappene er delt på jentens Story. Det innebærer at de er tilgjengelige for alle som er kontakter med Malin eller Kristine på Snapchat. Når det gjelder hvem denne kollektive mottakeren representerer, så forteller Malin og Kristine at de kommuniserer med folk i klassen eller andre venner. Malin skriver dessuten at det som er morsomt med snapping, er at man kan sende tekster til vennene sine. I tillegg skriver hun at det er morsomt med filtre. Kristine skriver noe tilsvarende. Hun forteller at det som er gøy er at man kan chatte med andre og bruke GIF og ulike filtre.

I den første snappen (t.v.) kombineres skrift, lyd, emojis og bevegelse. Filmsnutten varer i fire sekunder. Deltakerne Malin og Kristine er ikke representert i bildet, men de er likevel representert i den skriftlige delen av teksten ved hjelp av navnet til Kristine og «jeg» som er plassert øverst i snappen: «Nå lager X og jeg skjokoladeboller». Denne personlige ytringen er etterfulgt av to emojier: en fe-emoji og en smilende emoji med tre hjerter, og disse kan tolkes som uttrykk for positive følelser rundt bakesituasjonen.

Det mest fremskutte elementet i bakesnappen er den røde bakebollen som brukes til å dyppe sjokoladebollene i kokos. Bakebollen er plassert i midten, og den er også det største visuelle elementet i filmen. Bildeutsnittet giør at mottakeren kan oppleve bakesituasjonen på nært hold. Med andre ord framstår situasjonen som om mottakeren var til stede. I tillegg rister Malin på koppen mens hun filmer, noe som giør at mottakeren får høre og se en del av matlagingsprosessen. Bakebollen er delvis kontekstualisert, men bakgrunnen er likevel ikke spesielt tydelig. Man kan blant annet skimte underlaget og del av en annen bolle. Filtrering er ikke brukt i denne snappen. Kodingen er altså naturalistisk, og innholdet framstår dermed «slik situasjonen er».

I den andre snappen (t.h.) kombineres skrift og bilde. Det mest fremskutte elementet er den rosa isen som er plassert sentralt. Isen er også det største visuelle elementet. 
Øverst i snappen har Malin skrevet: «Nå går vi hjem fra skolen». Bakgrunnen, som viser fram asfalt på en vei eller et fortau, er forholdvis tydelig. Den står dessuten i fargemessig kontrast til den rosa isen. Hvor aktiviteten foregår, altså på vei hjem fra skolen, er altså uttrykt både i skrift og bilde. Den ene deltakerne (enten Malin eller Kristine) er representert i bildet ved hjelp av en skotupp. Innholdet i snappen er kodet sensorisk. Filtreringen gjør at isen blir glitrende, sanselig og fargesterk, og ved å bruke filteret oppnår jentene at isen framstår innbydende for mottakeren. At denne situasjonen oppleves som positiv, uttrykkes også ved hjelp av smilefjeset som er plassert rett etter skriften.

Det begge snappene har til felles, er at de dokumenterer og viser fram hverdagssituasjoner som er dagligdagse og vanlige, men likevel ideelle. Mottakeren inviteres til å være observatør, og han eller hun kan sette seg inn i jentenes situasjon. Måten innholdet kodes på, gjør at innholdet skal virke forlokkende på mottakeren. Innholdet representerer dermed ikke bare en ideell situasjon for Malin og Kristine, men den viser også fram en situasjon mottakeren vil kunne ønske seg å være i. Snappene imøtekommer dermed en kulturell forventning om at det man legger ut på sosiale medier skal være noe gledesfylt, positivt eller idealisert.

\section{Situasjon 4: Tilje (9) forteller om en fisk}

Tilje har sendt sju snapper. Hun har ikke Snapchat selv, men får av og til lov til å sende snap til familien fra morens telefon. Tilje sier dette om egen snapping: «Jeg sender ofte ikke snap men når jeg først gjør det er det til en gruppe hvor de i familien min er med». I snappen nedenfor har Tilje laget en muntlig fortelling om et menneske som plutselig har blitt forvandlet til en fisk. Snappen er ikke sendt til en mottaker.

Snappen består av bevegelig bilde og lyd. Det sentrale objektet i snappen er fisken, og Tilje går inn i rollen og snakker som fiskefiguren. Filteret tilbyr stemmeforvrengning,

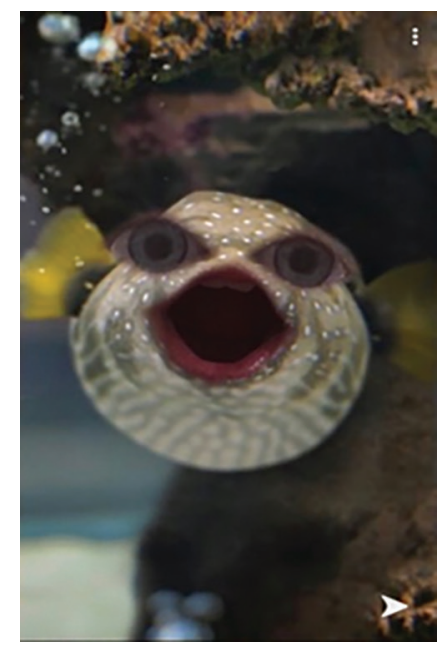

Figur 6. Tiljes snap 


\section{Michelsen}

og forvrengningen forsterker opplevelsen av ytringen som en rolleytring. Fisken har et ambivalent forhold til det å ha blitt en fisk, noe som uttrykkes slik:

Hallå folkens. Ja, jeg vet at jeg har blitt en fisk ass. Fisk ass. Haha! Seriøst! Jeg har blitt en fisk ass. Så nå svømmer jeg rundt i havet. Når jeg svømmer opp på land, får jeg mat og alt sånt, men jaja, jeg lever under vann. Ja, ja. Men jeg har fortsatt munn og tenner da. Ehehe. Hihi. Så, ha et fint liv da. Seriøst! Jeg har blitt en fiiiiisk!

Både fiskefilteret og stemmen til Tilje er framtredende ressurser i teksten. Øynene og munnen til fisken framstår som de mest framskutte elementene. De er plassert sentralt i snappen, og de beveger på seg. Fisken har direkte kontakt med den som ser filmen. Vi kan skimte noen detaljer i bakgrunnen som indikerer at fisken befinner seg under vann. Bakgrunnen som filteret tilbyr, utnytter Tilde i fortellingen når hun sier: «Nå svømmer jeg rundt i havet». Teksten representerer en utkledningssituasjon der Tilje kommuniserer med og underholder seg selv. Tilje svarer dermed på forventninger som ligger i verktøyet om å gå inn i forventede roller på liknende måte som Ida. Det som er påfallende i teksten til Tilje, er at hun helt konkret utnytter spenningsforholdet mellom den hun er i virkeligheten foran kameraet, og det hun ser ut som på skjermen. Fortellingen kan dermed forstås som en fortelling om Snapchat-verktøyet, og om det verktøyet har ført til, nemlig at hun har blitt forvandlet til en fisk. Fisken er dermed delvis en fiktiv karakter og delvis et uttrykk for at Tilje selv lever seg inn $\mathrm{i}$ opplevelsen av å ha blitt «forvandlet». Teksten speiler dermed både en fiktiv eller tenkt situasjon og en faktisk reell situasjon i møte med Snapchat-kameraet.

\section{Situasjon 5: Emil (9) lager en bursdagshilsen}

Emil har sendt fjorten snapper. Emil får ikke lov å ha egen Snachat-bruker, men han sier han ville sendt snapper til venner og familie hvis han fikk lov. Når det gielder hva Emil liker med snap, så sier han at han liker å ta bilder av seg selv og spille Snapchat-spill. Han sier også at snappene han har laget, handler om han selv. Snappen i figur 7 er en tekst som Emil har laget på morens mobil, og formålet er å gratulere moren med dagen.

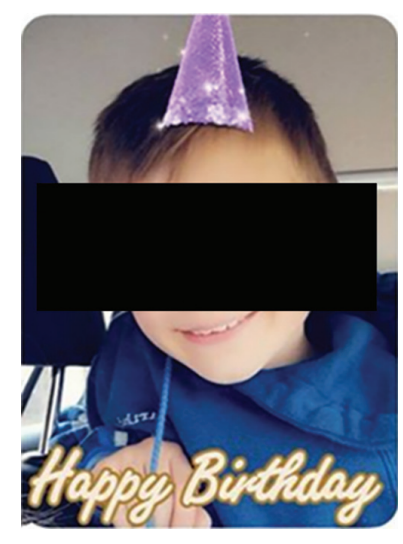

Figur 7. Emils snap 
Snappen er satt sammen av et bilde av Emil og et Happy-birthday-filter. Filteret består av skinnende, gule bokstaver med gullinnramming i tillegg til en lilla, glitrende bursdagshatt. Ansiktet til Emil er det mest sentralt plasserte tekstelementet, og selv om skriften og den lilla hatten vekker oppmerksomhet, så framstår også ansiktet til Emil som et viktig element. Den nære sosiale kontakten og positive følelser knyttet til bursdagen og moren, understrekes av at Emil smiler og ser direkte på mottakeren.

Fotografiet av Emil er naturalistisk kodet og viser Emil slik han ser ut til vanlig. Det samme gjelder bakgrunnen. Emil er delvis kontekstualisert, og man kan skimte toppen av et bilsete. Vi kan derfor slutte oss til at snappen er laget i bilen. Det hverdagslige stedet som bilen representerer, står i kontrast til det feststemte ved situasjonen som skriften symboliserer. Den glitrende skriften og bursdagshatten bidrar dermed til å giøre det vanlige og kjente, slik som bilen og Emil selv, til noe ekstraordinært. Teksten Emil har laget, er svar på en kulturell forventning ved at den gir uttrykk for hva det er relevant å si og ha på seg når noen har bursdag. Skriften uttrykker hva slags personlig ytring det er akseptabelt at Emil kommer med i en slik situasjon. Filteret vitner også om at det er forventet at avsenderen selv skal framstå som positiv, utkledt og glitrende.

\section{Situasjon 6: Oliver (12) stiller et spørsmål}

Oliver er blant de barna som får lov å bruke Snapchat, og han har sendt femten snapper. Når det gjelder hva snappene Oliver lager handler om, skriver han: «Snappene fra meg kommer til å handle om meg, mamma og søsteren min». Oliver skriver videre at det som er morsomt med Snapchat er at «det er mange kule filter som gir morsomme stemmer og grimaser». Oliver oppgir at det er venner og familie han kommuniserer med. Selfien i figur 8 henvender seg til moren med spørsmålet: «Når kommer du hjem i dag», og formålet er altså å be om informasjon.

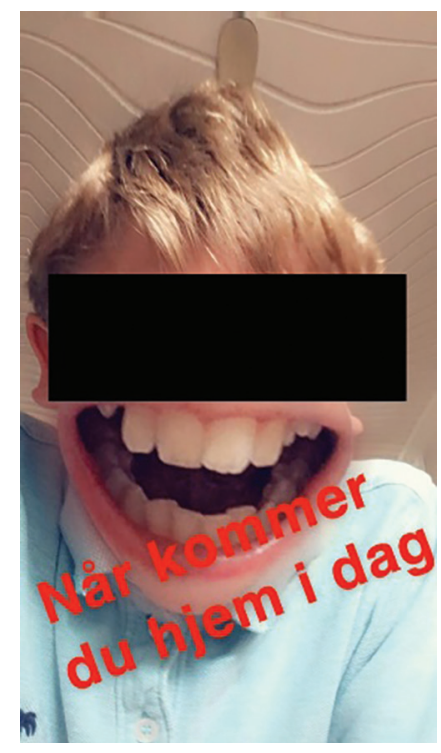


Teksten til Oliver består av skrift og bilde. Deltakeren Oliver er representert som objekt i bildet. Munnen, tennene og den skråstilte, røde skriften er de mest framtredende tekstelementene. Skriften er uthevet ved hjelp av størrelse og farge, og den står også i kontrast til den lyseblå genseren. Bakgrunnen er lite dominerende. Det er mulig å skimte et tak, noe som indikerer at Oliver befinner seg inne når han lager snappen. Det at spørsmålet dreier seg om når mottakeren kommer hjem, tyder på at Oliver selv befinner seg hjemme.

Den nære relasjonen mellom avsender og mottaker kommer å til syne i bildeutsnittet. Blikket til Oliver rettes direkte mot den som ser på bildet, og han kommer også tett på mottakeren gjennom måten det er tatt nærbilde på. Bildet er dessuten tatt litt skrått nedenfra, og det virker nærmest som om Oliver lener seg framover mot mottakeren. Sammen med de digre tennene og skriftutformingen bidrar undervinklingen til å understreke det tøysete og påtrengende i henvendelsesmåten. Det at skriften ligger delvis over munnen til Oliver, indikerer at det som står i skrift symboliserer en personlig ytring som skal tolkes humoristisk. Denne snappen er konvensjonell i den forstand at den representerer et vanlig samtalemønster, nemlig å utveksle informasjon i form av å stille spørsmål og få svar. Forventningen om at samtalen skal være morsom, ligger i det filteret Emil har valgt. Den hverdagslige henvendelsen framstår dermed som mindre ordinær enn om Emil bare hadde sendt en tekstmelding med det samme spørsmålet.

\section{Fellestrekk og ulikheter i datamaterialet}

I eksemplene som er vist over, har vi sett at mottakerne i de seks situasjonene enten er venner og familie, eller barnet selv. Et fellestrekk er også at snappene tematiserer hverdagshendelser som å kle seg ut, å gå hjem fra skolen, å bake, å sende hilsener eller å gjøre avtaler. Snappene formidler positive følelser rundt disse hendelsene. Barna uttrykker også gjennomgående at de er positivt innstilt til Snapchat-mediet, og når det gjelder svar på spørsmålet om det er noe de synes er dumt med Snapchat, så er svarene «ingen negative ting» eller «ikke noe spesielt». Ett av barna nevner at det er dumt hvis man sender bilder feil, og en annen nevner mobbeproblematikk, men dette er uttrykk for potensielle problemer, ikke utfordringer de selv har hatt.

Når det gjelder ordvalget i snappene, så speiler dette den private og fritidsforankrede konteksten. Ord og formuleringer i snappene er koblet til steder der barna befinner seg på fritiden: hjem, på vei hjem fra skolen, til barnas kropp: jeg, vi, mitt fjes og til situasjoner barnet deltar i: bursdag, spille. Snappene preges også av slang og muntlig, dagligdags språk: finne på no og engelske uttrykk: wanna hang, happy birthday. Mange av snappene er initiativer til samtaler, noe som også understrekes i ordbruk som hållå, heeei. Det at innholdet i snappene er preget av den private konteksten, og at tekstene er tiltenkt venner eller familiemedlemmer, understøttes også av de andre barna i studien. Flere påpeker at tekstene handler om fritiden eller om dem selv. Kristine formulerer det slik: «De handler om hva jeg gjør på fritida og hvem jeg er med», og Anna skriver: «De snapene jeg sender til deg handler om meg med fine filtre». 
I snappene som er analysert, er avstanden til personene som er avbildet nær eller halvnær. Dette er også et trekk som går igjen i det øvrige datamaterialet. Snappen som Anna har laget i figur 8, skiller seg noe ut, fordi det er lengre avstand til personen som er avbildet. Til tross for at denne snappen skaper avstand mellom Anna og mottaker på andre måter enn i det øvrige materialet, er også denne snappen uttrykk for en nær personlig relasjon. Snappen formidler et savn, noe som kommer til uttrykk i den skriftlige delen av teksten: «Hei X. Jeg savner deg! Klem fra X».

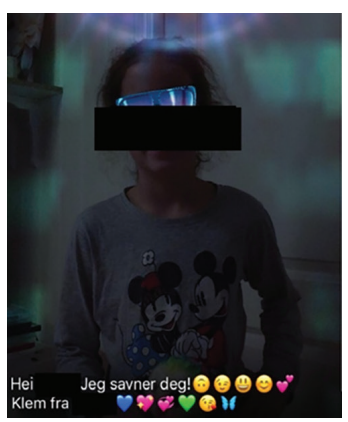

Figur 8. Annas snap

Som vi har sett tidligere, så har både Tilje og Ida benyttet verktøyet på en måte som kan forstås som selvkommunikasjon. Også flere av de andre barna utnytter verktøyet på denne måten, og materialet som helhet består i stor grad av selfier med utkledningsfilter. I figur 9 har Sofie benyttet et utkledningsfilter, og skriften kan tolkes som uttrykk for noe som sies. I så måte minner den om Idas og Tiljes rolleytringer. Felles for rolleytringene $\mathrm{er}$ at de representerer noe overdrevent, morsomt eller absurd. I Sofies tilfelle er det overdrevne markert gjennom den lange e-lyden. Det fins også andre måter å gå i interaksjon på verktøyet på enn å bruke utkledningsfilteret, og både Emil og Tilje har benyttet denne muligheten. Snappene i figur 10 er to svar på initiativ fra verktøyet. Emil har tegnet en strekmann nederst i høyre hjørne av skjermen slik det forslåes i innrammingen. Tilje har tatt bilde av ansiktet sitt der hun uttrykker det verktøyet foreslår.

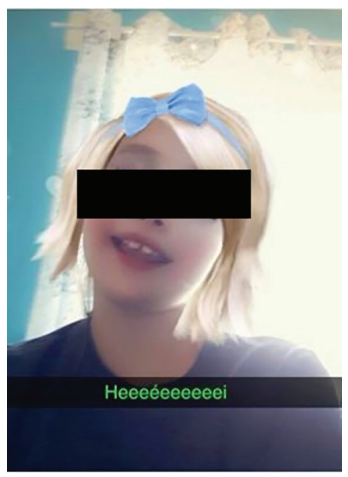

Figur 9. Sofies snap 

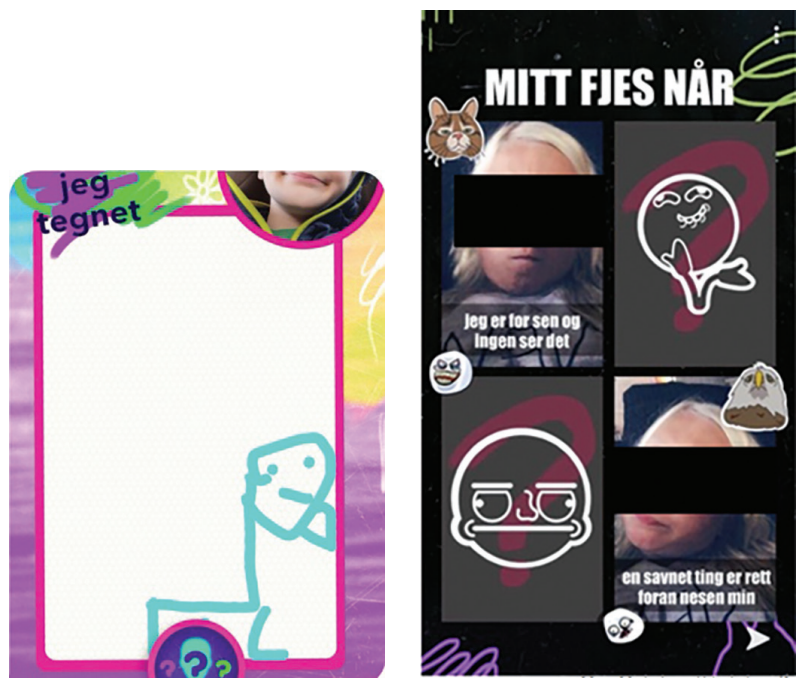

Figur 10. Emil og Tilje svarer på forslag fra verktøyet

Barnas snapper brukes til flere ulike formål og i ulike situasjoner. Dette er også tydelig i det øvrige datamaterialet. Når det gjelder å dokumentere hverdagshendelser, har Emil for eksempel sendt en snap til moren for å vise at han har klippet håret. Materialet inneholder også en snap der det å holde sosial kontakt er et kommunikativt formål i seg selv. Denne snappen vises i figur 11, og den er sendt fra Kristine til Malin. Snappen markerer en såkalt streak, som betyr at jentene har har holdt jevnlig kontakt over en periode, og denne formen for kontakt har et konkurransepreg over seg.

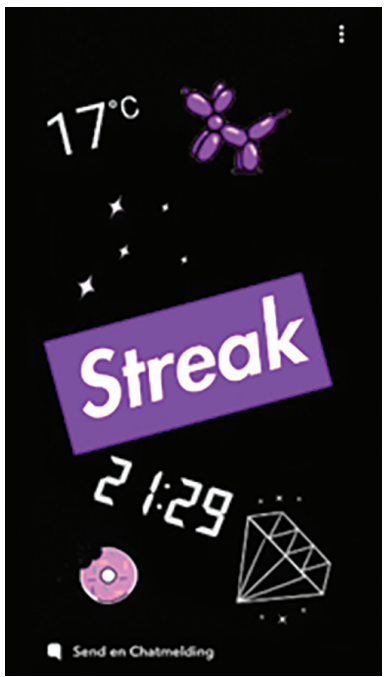

Figur 11. Kristines snap 
Den humoristiske og positive henvendelsesmåten er også et gjennomgående trekk i materialet. Vi har sett at Emil stilte et humoristisk spørsmål til moren. I snappen i figur 12 har Malin stilt et tilsvarende humoristisk spørsmål til Kristine: Heiii.Vil du finne på no? Snappen er både initiativ til en samtale og en aktivitet. Positive følelser rundt dette uttrykkes ved hjelp av emojis og lyse sommerfugler som flyr rundt Malins hode. Det humoristiske understrekes av undervinklingen av bildet, og dessuten av blikket som er vendt nedover mot skriften i den nederste delen av teksten.

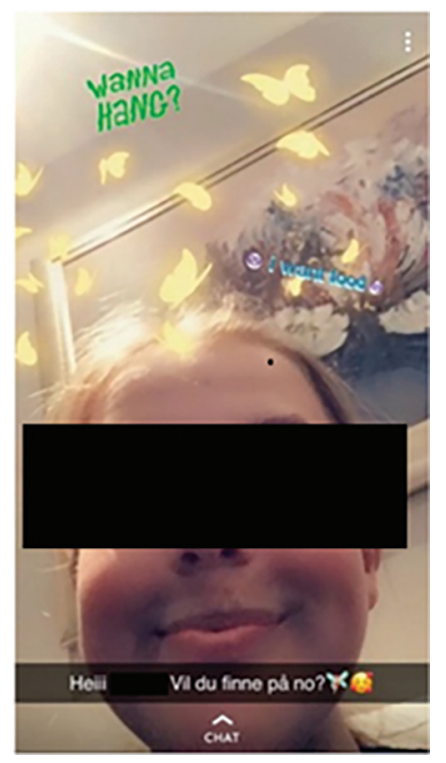

Figur 12. Malin henvender seg til Kristine

Det fins også fellestrekk med tanke på bruk av bakgrunn. I de tilfellene objekter i snappen er kontekstualiserte, sier bakgrunnen noe om steder der barnet beveger seg i privatlivet: i stua, i bilen, på kjøkkenet eller på vei hjem fra skolen. Dette gjelder også snappen i figur 13 som viser en kjøkkensituasjon ved juletider. Denne snappen, som Oliver har laget med søsteren som motiv, minner om Emils bursdagssnap. Den benytter et liknende filter med en engelskspråklig formulering, og også dette filteret gir uttrykk for forventninger knyttet til en feiring, i dette tilfellet julefeiringen. Filteret formidler hva slags farger som er vanlige (grønn og rød), hva slags ting man forbinder med julen (gaver, godterier, sløyfer og hjerter) og hva slags følelser som er akseptable (glede). Filteret representerer likevel ikke en klassisk nordisk julekontekst, men speiler snarere en amerikansk tradisjon. 


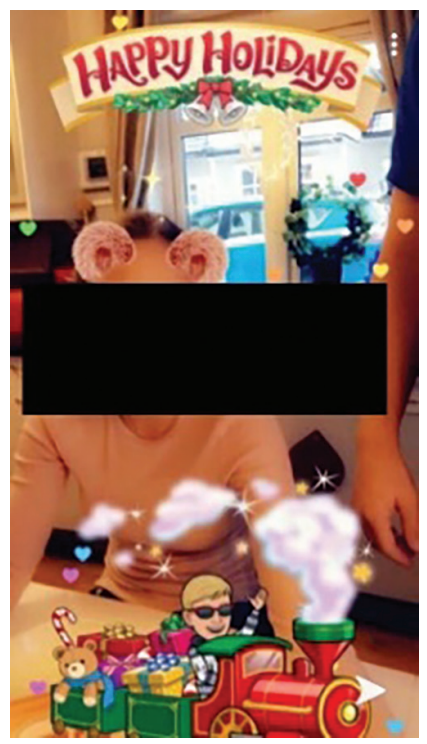

Figur 13. Snap med høytidstema

\section{Diskusjon}

Formålet med denne artikkelen er å undersøke hva som gjør det meningsfullt for barn å skape tekster på Snapchat. Analysene viser at barna bruker Snapchat til flere formål, og fleksibiliteten som ligger i verktøyet med tanke på hva det kan brukes til, kan sies å være en sentral drivkraft i tekstproduksjonen. Barna finner også det å sette sammen semiotiske ressurser meningsfullt i seg selv. Det å fiksjonalisere hverdagshendelser kan også sies å være en motivasjonsfaktor, og som helhet framstår tekstmaterialet som preget av humor og positive følelser. I Snapchat-tekstene som barna skaper, er det glidende overganger mellom det autentiske og det fiktive, der det fiktive framstår som viktigst. Hverdagshendelsene i barnas liv blir dermed gjort mer interessante enn det de er til vanlig. Det å lage mat, å klippe håret, å kle seg ut eller å gå hjem fra skolen, blir ikke lengre kun hverdagslige hendelser. Isteden fører måten tekstelementer settes sammen på, til at situasjonene framstår som helt spesielle. Det vanlige, selvsagte, og kanskje også kjedelige, i barnas hverdagsliv, forvandles til noe ikke-hverdagslig, morsomt og unikt.

Et annet trekk ved de sosiale situasjonene på Snapchat, er at barna kommuniserer med personer som står dem nære. I så måte er funnene sammenfallene med det Vaterlaus et al. (2016) og Piwek \& Joinson (2015) finner, nemlig at Snapchat brukes til å styrke allerede eksisterende sosiale bånd. Funnene viser imidlertid også at barna bruker snappingen til lek og til selvkommunikasjon, og i så måte må forestillingen om hvem som er barnas mottakere nyanseres noe. Tekstskapingen er ikke kun rettet mot noen andre utenfor teksten, den er også en måte å kommunisere med seg selv på. Det oppstår dermed ikke bare en nærkontakt mellom avsenderen og mottaker 
utenfor teksten, men barnet kan også ha kommunikativ nærkontakt med seg selv. Dette er særlig tydelig i de snappene der barna leker seg med kameraet eller bruker Snapchat-verktøyet til rollelek, men også de andre tekstene kan sies å være selvkommunikative i den forstand at barna setter seg selv inn i en idealisert eller forvrengt «virkelighet». Gjennom denne formen for tekstskaping kan de se, og dermed trolig også forstå, seg selv på nye måter.

Filtrene bidrar ikke bare til forvrengning og idyllisering. De bidrar også til å gi tekstproduksjonen en kroppslig dimensjon. I flere av tekstene er det deler av kroppen og aspekter ved den, som ansikt, hår, stemmer og fiktive kropper som fisker eller hunder, som er selve innholdet i teksten. Barna utvikler dermed en type sensorisk literacy, for å bruke Mills (2006) begrep, som er knyttet til filtrene. Men den kroppslige dimensjonen viser seg også på andre måter, først og fremst ved at barnet tar med seg sin kroppslige erfaring av å være i lek i møte med kameraet.

I tråd med Jovanovic \& van Leeuwen (2018) viser funnene i denne studien at barnas kommunikasjon drar veksler på hverdagssamtalen, særlig i form av å giøre avtaler eller innhente hverdagslig informasjon, men i tillegg inneholder materialet spor av andre muntlige og skriftlige sjangre. Vi finner både bursdags- og julehilsener, selvportretter, fortellinger og hverdagslige dokumentasjoner. Og ikke minst fins det spor av barns muntlige lekekultur i materialet. Dette er kommunikasjonsmåter som har eksistert lenger enn Snapchat-teknologien, og barnas tekster er dermed ikke uttrykk for noe genuint nytt, men de er uttrykk for allerede etablerte normer for måter å lage tekster på. Veum og Undrum (2018) finner en tydelig parallell mellom reklametekster og selfier, og det er også påfallende at snappene har likhetstrekk med reklametekster når det gjelder virkelighetsframstilling. Hverdagshendelsene barna deltar i, idylliseres og "selges inn" som noe attraktivt for mottakeren.

Til tross for spennet i sosiale situasjoner kan det hevdes at det forutsigbare ved verktøyet er begrensende med tanke på hva som kan kommuniseres, og hvordan det kan kommuniseres. Barnet går med på de utkledningsreglene som initieres av verktøyet: å være en bestemt dyrefigur, eller å være rar og morsom. Barna er dermed ikke frie til å spille ut hvilke roller som helst. Når de bruker verktøyet til lekeformål, kan de ikke forhandle om reglene på samme måte som i den tradisjonelle rolleleken. Videre velger barna ofte å bruke et bildeutsnitt der bildene er nære eller halvnære, selv om det fins muligheter til å velge dette bort. Tekstene bærer også preg av sosiale og kulturelle forventninger knyttet til høytider og feiringer, og ikke minst hvordan det er forventet at innholdet på sosiale medier skal pakkes inn som noe positivt og ekstraordinært. Oppsummert kan barnas snapper ses på som multimodale svar på ulike sosiale, kulturelle og tekniske forventninger.

Til slutt vil jeg drøfte noen didaktiske implikasjoner av disse funnene som angår barns motivasjon for tekstskaping i andre sammenhenger, slik som på skolen. I denne delen av diskusjonen vil jeg også trekke inn hvordan kritisk tilncerming til tekst kan ses i sammenheng med barnas tekstpraksis på Snapchat. Det er ingen av barna som trekker fram begrensningene i verktøyet, eller som sier at muligheten for bilderedigering er 
negativ. Isteden er de gjennomgående positivt innstilt til verktøyet. Det er heller ingen som er negative til måtene filtrene bidrar til idyllisering av virkeligheten på. Selv om vi har sett at filtrene er begrensende med tanke på hva slags innhold som skapes og hvordan det skal forstås, så oppleves de mange mulighetene for kompleks meningsskaping som positivt blant barna. Dette er sammenfallende med funn fra studien til Undrum \& Veum (2018), og de peker på at heller ikke elever på videregående reflekterer over medienes makt til å definere innhold. Dersom tekster på sosiale medier skal drøftes i faglig sammenheng, er mediets begrensninger og muligheter noe som bør tematiseres tidlig i skoleløpet.

Det å utvikle kritisk tekstkompetanse i møte med tekster på sosiale medier, kan også handle om at elevene får bevissthet om hvordan tekster på sosiale medier drar veksler på andre sjangre og kommunikasjonsformer. Det er påfallende at barna opplever sine egne tekster som personlige og unike, ikke som uttrykk for felles måter å kommunisere på i kulturen. Å bevisstgjøre barn og unge på snappenes mangfoldighet, og å trekke paralleller til eksempelvis reklametekster, mener jeg kan bidra til kritisk tekstkompetanse. Da er det også viktig at lærerne vet noe om hva elevene allerede kan, og at de kjenner til de tekst- og sjangererfaringene elevene får på fritiden. Tekstanalysene i denne studien har blant annet vist at barna har gode hverdagskunnskaper om hvordan man setter sammen tekstelementer på humoristiske måter, hvordan man skaper tekster som skal avkodes forholdvis raskt av mottakeren og hvordan et dagligdags innhold kan gjøres interessant og attraktivt. Barna i denne studien motiveres også av den rike semiotiske tilgangen på Snapchat, og de finner det å sette sammen tekstelementer meningsfullt i seg selv. Barna er i mindre grad opptatte av begrensningene i verktøyet og de stereotype framstillingsmåtene som mediet legger opp til.

\section{Forfatteromtale}

Maja Michelsen er førsteamanuensis i norsk ved avdeling for lærerutdanning ved Høgskolen i Østfold. Hun forsker på barn, medier, literacy og multimodalitet og har blant annet skrevet doktorgradsavhandling om barns bruk av Internett.

\section{Referanser}

Barton, D. \& Hamilton, M. (2003). Local literacies. Reading and writing in one community. London: Routledge. Burn, A. \& Parker, D. (2003). Analysing media texts. London: Bloomsbury Pulishing.

Bryman, A. (2016). Social research methods (5. utg.). Oxford: Oxford University Press.

Halliday, M. A. K. (1998). Situasjonskonteksten. I K. L. Berge, P. Coppock \& E. Maagerø (Red.), $A$ skape mening med språk. En samling artikler av M. A. K Halliday, R. Hasan E f. R. Martin. Oslo: LNU/Cappelen Akademisk Forlag.

Hilmarsen, H. V. \& Arnseth, H. C. (2017). Livet på Instagram. Ungdoms digitale forlengelser av sosiale relasjoner og vennskap. Tidsskrift for ungdomsforskning, 17(1). Hentet fra https://journals.hioa.no/index. php/ungdomsforskning/article/view/2109

Hopperstad, M. H. (2005). Alt begynner med en strek. Oslo: Cappelen Akademisk Forlag.

Høigård, A. (2013). Barns språkutvikling. Muntlig og skriftlig (3. utg.). Oslo: Universitetsforlaget. 


\section{Barns tekstproduksjon på Snapchat}

Jovanovic, D. \& Van Leeuwen, T. (2018). Multimodal dialogue on social media. Social semiotics, 28(5), $683-699$. https://doi.org/10.1080/10350330.2018.1504732

Juuhl, G. K. (2014). I det mykje skrivne. Ei undersøking av ungdoms digitale tekstar $i$ skule og fritid som situerte, retoriske handlingar. (Doktorgradsavhandling, Universitetet i Oslo). Hentet fra http://urn.nb.no/URN: NBN:no-39811.

Juuhl, G. K. \& Michelsen, M. (2020). Forsking på barn og ungdoms tekstar og tekstpraksisar på fritida, med eit nordisk fokus. Nordic fournal of Literacy Research, Special issue: Barn og unges tekstpraksiser i fritiden, vol. 6(3).

Kress, G. \& van Leeuwen, T. (2006). Reading images. The grammar of visual design (2. utg.). London: Routledge.

Ledin, P. \& Machin, D. (2018). Doing visual analysis. From theory to practice. London: Sage Publications.

Lindstrand, F. (2011). Att erkänna och urskilja: Ett designorienterat multimodalt fokus på barns meningsskapande. I J. Smidt, E. S. Tønnessen \& B. Aamotsbakken (Red.), Tekst og tegn. Lesing, skriving og multimodalitet $i$ skole og samfunn. Trondheim: Tapir Akademiske Forlag.

Lorentzen, R. (2009). Den tidlege skriveutviklinga. I J. Smidt (Red.), Norskdidaktikk (3. utg.). Oslo: Universitetsforlaget.

Medietilsynet. (2016). Barn og medier. 9-16-åringers bruk og opplevelser av medier. Fredrikstad: Medietilsynet. Hentet fra https://medietilsynet.no/globalassets/publikasjoner/barn-og-medier-undersokelser/2016_barnogmedier. pdf. Lastet ned. 30.11.19.

Medietilsynet. (2018). Barn og medier-undersøkelsen 2018. 9-18-åringer om medievaner og opplevelser. Hentet fra https:/www.medietilsynet.no/globalassets/publikasjoner/barn-og-medier-undersokelser/2018-barn-ogmedier.

Miller, C. (2001). Genre som social handling. Rhetorica Scandinavia, 18, 19-35. Hentet fra https://www. retorikforlaget.se/genre-som-sosial-handling/

Mills, K. A. (2016). Literacy theories for the digital age. Social, critical, multimodal, spatial, material and sensory lenses. Bristol: Multilingual Matters.

Piwek, L. \& Joinson, A. (2016). «What do they snapchat about?» Patterns of use in time-limited instant messaging service. Computers in Human Behavior, 54, 358-367. https://doi.org/10.1016/j.chb.2015.08.026

Rettberg, J. W. (2014). Seeing ourselves through technology. How we use selfies, blogs and wearable devices to see and shape ourselves. New York: Palgrave Macmillan.

Rettberg, J.W. (2017). Hand signs for lip-syncing: The emergence of a gestural language on musical.ly as a videobased equivalent to emoji. Social media + Society, 3(4), 1-11. https://doi.org/10.1177/2056305117735751

Ringdal, E. (2002). 16 år og tekstmeldar: Stadig myldrande skriving (SMS). I J. L. Tønnesson (Red.), Den flerstemmige sakprosaen. Bergen: Fagbokforlaget/LNU.

Semundseth, M. \& Hopperstad, M. H. (Red.). (2013). Barn lager tekster. Om barns tidlige tekstproduksjon og de voksnes betydning. Oslo: Cappelen Damm Akademisk.

Skårderud, F. (2013, 5. april). Selviakttakelsen. Om øyet, ansiktet og kroppen i speilet. Om selvportrettet som portretter av selvet gjennom tidene. Tidsskrift for norsk psykologiforening. Hentet fra https:// psykologtidsskriftet.no/fagartikkel/2013/04/selviakttakelsen

Undrum, L. \& Veum, A. (2018). Kritisk literacy i den digitale tekstkulturen. Unges selvframstilling i og selvrefleksjon over kommunikasjon i sosiale medier. I K. Kverndokken (Red.), 101 litteraturdidaktiske grep - om å arbeide med skjønnlitteratur og sakprosa. Bergen: Fagbokforlaget.

Vaterlaus, M. J., Barnett K., Roche, C. \& Young, J. (2016). «Snapchat is more personal»: An exploratory study on Snapchatbehaviours and young adult interpersonal relationship. Computers in Human Behavior, 62, 594-601. https://doi.org/10.1016/j.chb.2016.04.029

Veum, A. (2013). «Blogging på rosa skjerm. Om roller og relasjonar i ungjentebloggar». I S. Hållsten, H. S. Rehnberg \& D. Wojahn (Red.), Sex nordiska studier i systemisk-funktionell lingvistik (s. 107-124). Stockholm: Elanders.

Veum, A. \& Undrum, L. (2018). The selfie as a global discourse. Discourse E Society, 29(1), 86-103. https://doi. org/10.1177/0957926517725979

Wernholm, M. (2018). Children's shared experiences of participating in digital communities. Nordic fournal of Digital Literacy, 13(4), 8-35. https://doi.org/10.18261/issn.1891-943x-2018-04-04 